\title{
Phytoplankton response to a plume front in the northern South China Sea
}

\author{
Qian P. Li ${ }^{1,2}$, Weiwen Zhou ${ }^{1,2}$, Yinchao Chen ${ }^{1,2}$, and Zhengchao Wu ${ }^{1}$ \\ ${ }^{1}$ South China Sea Institute of Oceanology, Chinese Academy of Sciences, Guangzhou 510301, China \\ ${ }^{2}$ University of Chinese Academy of Sciences, Beijing 100049, China \\ Correspondence: Qian P. Li (qianli@scsio.ac.cn)
}

Received: 20 November 2017 - Discussion started: 15 December 2017

Revised: 15 March 2018 - Accepted: 4 April 2018 - Published: 27 April 2018

\begin{abstract}
Due to a strong river discharge during AprilJune 2016, a persistent salinity front, with freshwater flushing seaward on the surface but seawater moving landward at the bottom, was formed in the coastal waters west of the Pearl River estuary (PRE) over the northern South China Sea (NSCS) shelf. Hydrographic measurements revealed that the salinity front was influenced by both the river plume and coastal upwelling. On shipboard nutrient-enrichment experiments with size-fractionation chlorophyll $a$ measurements were taken on both sides of the front as well as in the frontal zone to diagnose the spatial variations of phytoplankton physiology across the frontal system. We also assessed the size-fractionated responses of phytoplankton to the treatment of plume water at the frontal zone and the sea side of the front. The biological impact of vertical mixing or upwelling was further examined by the response of surface phytoplankton to the addition of local bottom water. Our results suggested that there was a large variation in phytoplankton physiology on the sea side of the front, driven by dynamic nutrient fluxes, although P limitation was prevailing on the shore side of the front and at the frontal zone. The spreading of plume water at the frontal zone would directly improve the growth of microphytoplankton, while nano- and picophytoplankton growths could have become saturated at high percentages of plume water. Also, the mixing of bottom water would stimulate the growth of surface phytoplankton on both sides of the front by altering the surface N/P ratio to make it closer to the Redfield stoichiometry. In summary, phytoplankton growth and physiology could be profoundly influenced by the physical dynamics in the frontal system during the spring-summer of 2016.
\end{abstract}

\section{Introduction}

It is well known that physical dynamics in the coastal ocean can be strongly influenced by river input. When there is a high river discharge, a large plume of brackish water can form near the estuary mouth and the adjacent inner shelf regions, which is generally a low-salinity mesoscale feature that disperses fresh river water across the coastal margin (Horner-Devine et al., 2015). River plumes can transport and redistribute river-borne materials, such as nutrients and particles and thus largely affect the biogeochemistry of the coastal ocean (Dagg et al., 2004; Lohrenz et al., 2008). Convergent surface fronts over the shelf are a common feature associated with river plumes (e.g., Garvine and Monk, 1974). These plume-induced fronts are often places of high phytoplankton productivities (Acha et al., 2004) and thus provide important feeding and reproductive habitats for higher trophiclevel marine organisms, such as zooplankton and fish (Morgan et al., 2005).

Biological production in the coastal northern South China Sea (NSCS) is controlled by monsoon-driven upwelling that brings nutrient-rich deep water to the shelf (Liu et al., 2002). In addition, there is an intense river discharge from the Pearl River estuary (PRE) during the spring-summer leading to the development of a strong nearshore river plume (Su, 2004). In the coastal water, west of the PRE, convergence between the northeastward coastal current and the southeastward river plume can maintain a sharp salinity front along the shelf when the southwesterly monsoon is prevailing over the region (Wong et al., 2003). Variability at the front is primarily controlled by the river discharge and by the direction and magnitude of the regional wind field (Dong et al., 2004). To the east of the PRE, the surface plume water can be entrained 
in the coastal current as a salinity tongue in the summer and propelled eastward and offshore by wind-driven jets to affect a large area of the NSCS shelf sea (Gan et al., 2009).

The plume front over the NSCS shelf creates an interface between the river plume and the adjacent marine waters with rapid changes in both salinity and nutrients at the frontal zone (e.g., Cai et al., 2004). There is a P limitation of phytoplankton growth in the river plume due to a high $\mathrm{N} / \mathrm{P}$ ratio of the PRE water (Zhang et al., 1999; Yin et al., 2001). In contrast, biological production is generally $\mathrm{N}$ limited in the offshore oceanic waters (Wu et al., 2003; Chen et al., 2004), as the upwelled deep water with an N/P ratio of $\sim 14$ is essentially $\mathrm{N}$ deficient compared to the Redfield $\mathrm{N} / \mathrm{P}$ ratio of 16 (Wong et al., 2007). A shift from $\mathrm{P}$ limitation to $\mathrm{N}$ limitation in the phytoplankton community has been speculated across the plume edge to the sea based on the results of the Hong Kong waters (Yin et al., 2001). The results of a physical-biogeochemical coupling model in the NSCS indeed predict a fast decrease in N/P ratio from $\sim 120$ in the near-field to $<13.3$ in the far-field of the plume front driven by a higher $\mathrm{N} / \mathrm{P}$ consumption ratio and by mixing with the ambient lower N/P water (Gan et al., 2014).

Nutrient variations, in addition to light fluctuation, can affect the partitioning of phytoplankton biomass between different size classes (Marañón et al., 2012, 2015). The change in phytoplankton size structure can be controlled by sizedependent tradeoff processes for resource acquisition and use (Marañón, 2015). Small phytoplankton has a higher nutrient affinity for growth under nutrient-limiting conditions (Suttle, 1991; Raven et al., 1998), whereas large phytoplankton shows higher growth efficiency under favorable nutrient conditions (Cermeño et al., 2005). A large shift in phytoplankton assemblage from small to large cells could arise following the addition of nutrients from deep seawater in the North Pacific Subtropical Gyre (McAndrew et al., 2007; Mahaffey et al., 2012). The success of large phytoplankton in the oligotrophic ocean would largely depend on external environmental dynamics, although it has the metabolic potential of enhancing production (Alexander et al., 2015). It is thus important to understand not only the mechanisms for nutrient variations but also the response of the size-fractionated phytoplankton community to the diverse nutrient supplies, particularly at the frontal zone where the patchiness of phytoplankton can be affected by complex physical dynamics ( $\mathrm{Li}$ et al., 2012).

Three field surveys were carried out to study the biological response to a strong salinity front over the NSCS shelf during April-June of 2016. Besides comprehensive hydrographic and biogeochemical measurements, such as temperature, salinity, nutrients and chlorophyll $a$, we performed nutrient-enrichment experiments with sizefractionation chlorophyll $a$ measurements at the shore side, the frontal zone and the sea side of the front to examine the spatial change in phytoplankton physiology. Phytoplankton response to the river plume at the frontal zone was addressed

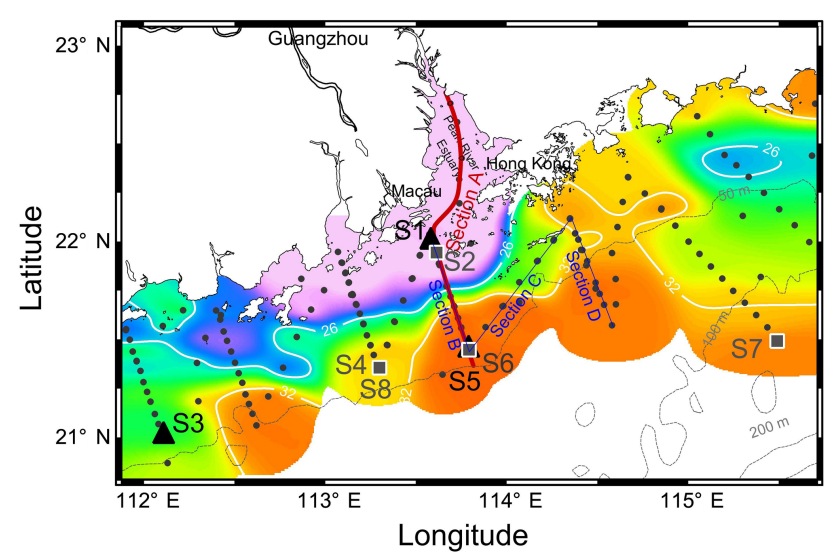

Figure 1. Sampling map in the NSCS shelf during May-June 2016. Color is the surface salinity of three cruises with the frontal zone by white lines of 26 and 32 (nearshore and offshore boundaries of the plume). Section A is across the front from the PRE to the shelf; section $\mathrm{B}$ is across the front with sections $\mathrm{C}$ and $\mathrm{D}$ on the sea side. Triangles are incubation sites S1, S3 and S5 during May 2016 and squares are incubation sites S2, S4, S6, S7 and S8 during June 2016. Locations of S6 and S8 are overlaid with S5 and S4, respectively. Dots are the stations and dashed lines are the isobaths.

by mixing the local surface water with a varying percentage of plume water from the shore side of the front. The impact of the river plume on the sea side of the front was further examined by incubations of the surface seawater with the treatment of plume water. In addition to these experiments, the bottom water was added to the surface water for incubation at various zones of the frontal system to estimate the impact of vertical mixing or upwelling on the surface phytoplankton community. We hope to use these experimental approaches to address the responses of phytoplankton growth and physiology to the strong salinity front over the shelf. Based on these field results, we will also discuss the impacts of the river plume, vertical mixing and coastal upwelling on physical and biogeochemical dynamics in the frontal systems in the NSCS shelf sea.

\section{Material and methods}

\subsection{Description of the field work}

Three field cruises aboard R/V Zhanjiang Kediao took place in April, May and June in 2016 with hydrographic and biogeochemical sampling over the NSCS shelf (Fig. 1). A vertical transect across the salinity front from the inner estuary to the shelf was intensively sampled during June (Section A in Fig. 1). There were three other transects (sections B$D$ in Fig. 1) outside the PRE with intense size-fractionation chlorophyll $a$ measurements during both May and June. Section $\mathrm{B}$ transited across the frontal zone with sections $\mathrm{C}$ and $\mathrm{D}$ on the sea side of the front. Surface waters in different zones 
of the salinity front were selected for nutrient-enrichment experiments, including the shore side of the front ( $\mathrm{S} 1$ and $\mathrm{S} 2$ ), the frontal zone (S3 and S4) and the sea side of the front (S5, S6 and S7) during May and June 2016. Station S8 is located in the same place as $\mathrm{S} 4$ but was in use 9 days later.

\subsection{Measurements of hydrography, chlorophyll $a$, nutrients and phytoplankton size structure}

Seawater temperature, salinity, pressure and fluorescence were acquired using a Sea-Bird model SBE9/11 conductivity-temperature-depth (CTD) recorder and a Chelsea Aquatracka fluorometer. Discrete water samples at 1, 20, 40, 60, 80 and $100 \mathrm{~m}$ were collected with Niskin bottles mounted onto a Rosette sampling assembly (General Oceanic). After filtration onto a Whatman GF/F glass fiber filter, the chlorophyll $a(\mathrm{Chl}-a)$ sample was extracted by $90 \%$ acetone in darkness at $4{ }^{\circ} \mathrm{C}$ for $24 \mathrm{~h}$ and determined using a Turner Design fluorometer (Knap et al., 1996). Three types of filters $(20 \mu \mathrm{m}$ nylon filter, $2 \mu \mathrm{m}$ polycarbonate filter and $0.7 \mu \mathrm{m} \mathrm{GF/F} \mathrm{filter)} \mathrm{were} \mathrm{used} \mathrm{to} \mathrm{produce} \mathrm{three} \mathrm{different}$ size classes including micro- $(>20 \mu \mathrm{m})$, nano- $(2-20 \mu \mathrm{m})$ and picophytoplankton $(0.7-2 \mu \mathrm{m})$. Nutrient samples were collected inline through a Whatman GF/F filter and frozen immediately at $-20^{\circ} \mathrm{C}$ until analyzed. After thawing at room temperature, they were analyzed by an AA3 nutrient auto-analyzer using colorimetric methods (Knap et al., 1996) with detection limits of $0.02,0.02$ and $0.03 \mu \mathrm{molL}^{-1}$, for nitrate plus nitrite $(\mathrm{N}+\mathrm{N})$, soluble reactive phosphate (SRP) and silicate $(\mathrm{Si})$, respectively.

\subsection{Setup of the shipboard incubation experiments}

There were four different treatments prepared in duplicate for nutrient-enrichment experiments including the control (C), nitrogen alone $(+\mathrm{N})$, phosphorus alone $(+\mathrm{P})$ and nitrogen plus phosphorus $(+\mathrm{NP})$. Nutrients were added to the incubation bottle based on the Redfield $\mathrm{N}$ : $\mathrm{P}$ ratio to obtain final concentrations of $4.8 \mu \mathrm{M} \mathrm{NaNO}_{3}$ and $0.3 \mu \mathrm{M} \mathrm{NaH}_{2} \mathrm{PO}_{4}$. Seawater samples were prescreened through a $200 \mu \mathrm{m}$ mesh to remove large grazers. These samples were incubated in $2.4 \mathrm{~L}$ transparent acid-cleaned polycarbonate bottles and placed in a shipboard incubation chamber equipped with a flowthrough seawater system. The incubator was shaded using a neutral filter to mimic $30 \%$ sunlight, with each bottle being manually stirred twice a day. Nutrient-addition experiments were performed at S1, S3 and S5 during May 2016 and S2, S4, S6, S7 and S8 during June 2016 (Table 1). Each incubation experiment was conducted immediately upon reaching the station and lasted for 2 days with size-fractionated chlorophyll $a$ and nutrient samples taken once a day.

Surface water $(\sim 50 \mathrm{~L})$ collected at S2 outside the PRE mouth was saved as the plume water (PW). Half of the PW was filtered through a $0.2 \mu \mathrm{m}$ Millipore membrane filter (GTTP Isopore ${ }^{\mathrm{TM}}$ ) to produce the filtered plume water
(FPW). The FPW was used to dilute the local surface waters at S6, S7 and S8 by a fraction of $12.5 \%$. At station S6, the raw plume water ( $\mathrm{PW}$ ) was also added to the surface water for incubation to test the possible advective chlorophyll input by the river plume. Under the in-situ temperature and light, the mixture was incubated on board for 2 days with size-fractionation chlorophyll $a$ collected each day. In order to examine the response of a mixed phytoplankton community at the frontal zone to various mixing conditions driven by the dispersive river plume, we also conducted a series of mixing experiments between the surface waters of S2 and S4 on 19 June 2016, with the final percentages of S4, $25 \%$ $\mathrm{S} 2+75 \% \mathrm{~S} 4,50 \% \mathrm{~S} 2+50 \% \mathrm{~S} 4,75 \% \mathrm{~S} 2+25 \% \mathrm{~S} 4$ and $\mathrm{S} 2$ corresponding to the final salinity of $30.7,24.7,18.7$, 12.7 and 6.6, respectively. The bottom waters (BW) were collected at S2, S4, S6 and S7 and stored in clean HDPE carboy. A $0.2 \mu \mathrm{m}$ filtration was used to create the filtered bottom water (FBW). Both BW and FBW, with a final percentage of $12.5 \%$, were added to the local surface water for incubation to study the impact of vertical mixing or upwelling on phytoplankton growth at these stations.

For each size class, the rate of daily chlorophyll $a$ production $\left(\mu \mathrm{gL}^{-1} \mathrm{~d}^{-1}\right)$ was calculated by the difference in size-fractionated chlorophyll $a$ concentration on each incubation day. We also estimated the net growth rates $\mu\left(\mathrm{d}^{-1}\right)$ for the water-mixing experiment between $\mathrm{S} 2$ and $\mathrm{S} 4$ by $\mu=\ln \left(\mathrm{Chl}_{1} / \mathrm{Chl}_{0}\right) / \Delta t$, with $\mathrm{Chl}_{0}$ and $\mathrm{Chl}_{1}$ being the initial and final size-fractionated chlorophyll $a$ concentrations every day ( $\Delta t=1$ day). The specific growth rate approach could not work for other experiments, as large errors of $\mu$ would arise when the initial chlorophyll $a$ of a certain size class $\left(\mathrm{Chl}_{0}\right)$ is close to zero.

\subsection{Estimations of horizontal advection and vertical mixing at the sea side of the front}

Assuming a salinity balance at the seaward front (Fong and Geyer, 2001), we have

$U_{\mathrm{e}}\left(S_{0}-S\right)=K_{H} \frac{\partial S}{\partial z}$,

where $S$ and $S_{0}$ are salinity of the plume front and ambient water, $K_{H}$ is the eddy diffusivity, and the bulk entrainment rate $U_{\mathrm{e}}$ is computed by $U_{\mathrm{e}} \approx 0.038 R i^{-0.5}(\tau / \rho)^{0.5}$ with the Richardson number $(R i)$ given by

$R i=\frac{g \rho}{\tau \rho_{0}} \int_{0}^{h}\left(\rho_{0}-\rho\right) \mathrm{d} z$,

with $g$ the gravitational acceleration, $\rho_{0}$ the ambient density, $h$ the thickness of plume front and $\tau$ the wind stress (Fong and Geyer, 2001).

Horizontal nitrate flux to the surface water on the sea side of the front can thus be estimated by $J_{h}=U_{\mathrm{e}}\left(N-N_{0}\right)$ with 
Table 1. Hydrographic and biogeochemical properties of the surface and bottom waters for incubations over the NSCS shelf during May and June 2016. Nutrient-addition experiments and water-mixing experiments were conducted immediately after we reached these stations.

\begin{tabular}{|c|c|c|c|c|c|c|c|c|c|c|c|c|}
\hline Station & Date & $\begin{array}{c}\text { Depth } \\
(\mathrm{m})^{*}\end{array}$ & $\begin{array}{r}T \\
\left({ }^{\circ} \mathrm{C}\right)\end{array}$ & $\begin{array}{r}\mathrm{S} \\
(\% \circ)\end{array}$ & $\begin{array}{r}\text { Chl-a } \\
\left(\mu \mathrm{gL}^{-1}\right)\end{array}$ & $\begin{array}{r}\text { micro } \\
(\%)\end{array}$ & $\begin{array}{r}\text { nano } \\
(\%)\end{array}$ & $\begin{array}{r}\text { pico } \\
(\%)\end{array}$ & $\begin{array}{r}\mathrm{Si} \\
(\mu \mathrm{M})\end{array}$ & $\begin{array}{r}N+N \\
(\mu M)\end{array}$ & $\begin{array}{l}\text { SRP } \\
(\mu \mathrm{M})\end{array}$ & $\mathrm{N} / \mathrm{P}$ \\
\hline \multirow[t]{2}{*}{ S1 } & 18 May & 1 & 24.5 & 20.4 & 7.01 & 73.8 & 14.3 & 11.9 & 34.1 & 33.3 & 0.22 & 151 \\
\hline & & 10 & 23.6 & 31.7 & 7.93 & 37.4 & 5.6 & 56.9 & 16.4 & 20.1 & 0.32 & 63 \\
\hline \multirow[t]{2}{*}{ S2 } & 19 June & 1 & 29.1 & 6.6 & 6.82 & 19.9 & 65.8 & 14.2 & 192.5 & 80.4 & 0.83 & 97 \\
\hline & & 8 & 25.6 & 34.0 & 0.31 & 12.1 & 65.3 & 22.5 & 43.9 & 16.7 & 0.65 & 28 \\
\hline \multirow[t]{2}{*}{ S3 } & 15 May & 1 & 27.9 & 30.9 & 0.91 & 35.3 & 39.2 & 25.5 & 3.2 & 16.6 & 0.13 & 127 \\
\hline & & 50 & 20.9 & 34.5 & 0.34 & 17.9 & 43.2 & 38.9 & 4.3 & 7.7 & 0.22 & 35 \\
\hline \multirow[t]{2}{*}{ S4 } & 18 June & 1 & 30.0 & 30.7 & 1.24 & 5.5 & 43.8 & 50.7 & 1.2 & 6.6 & 0.21 & 32 \\
\hline & & 39 & 21.7 & 34.6 & 0.91 & 4.9 & 32.6 & 62.5 & 10.8 & 6.1 & 0.23 & 26 \\
\hline \multirow[t]{2}{*}{ S5 } & 19 May & 1 & 26.6 & 34.4 & 0.26 & 1.3 & 8.8 & 89.9 & 1.4 & 1.0 & 0.09 & 12 \\
\hline & & 36 & 23.8 & 34.3 & 0.15 & 15.0 & 27.9 & 57.1 & 2.0 & 1.3 & 0.11 & 11 \\
\hline \multirow[t]{2}{*}{ S6 } & 19 June & 1 & 30.7 & 34.5 & 0.73 & 0.3 & 23.8 & 75.8 & 2.2 & 0.5 & 0.14 & 3 \\
\hline & & 47 & 21.7 & 34.7 & 0.45 & 9.2 & 21.0 & 69.8 & 9.3 & 3.6 & 0.17 & 21 \\
\hline \multirow[t]{2}{*}{ S7 } & 21 June & 1 & 30.8 & 32.1 & 0.59 & 0.7 & 45.1 & 54.2 & 1.3 & 3.3 & 0.07 & 46 \\
\hline & & 109 & 19.2 & 34.7 & 0.07 & 1.4 & 11.0 & 87.6 & 13.3 & 9.2 & 0.61 & 15 \\
\hline \multirow[t]{2}{*}{ S8 } & 27 June & 1 & 31.3 & 30.9 & 0.33 & 10.0 & 44.7 & 45.3 & 2.65 & 3.0 & 0.18 & 17 \\
\hline & & 39 & 21.7 & 34.6 & 0.91 & 4.85 & 32.9 & 64.7 & 6.69 & 4.9 & 0.27 & 18 \\
\hline
\end{tabular}

* The depth of surface water is always at $\sim 1 \mathrm{~m}$ with the depth of bottom water $5-10 \mathrm{~m}$ above the topography.

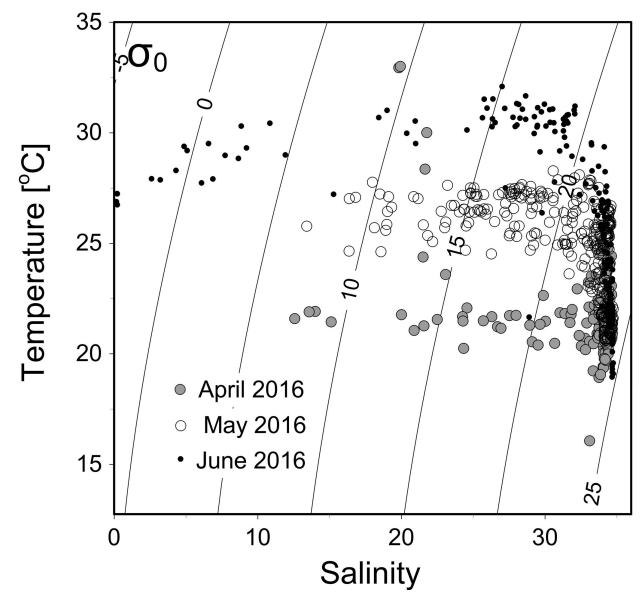

Figure 2. A temperature vs. salinity diagram during AprilJune 2016. Filled circles, open circles and dots are data from April, May and June cruises, respectively.

$N$ and $N_{0}$ the nutrient concentrations of the plume front and the ambient water. The vertical nitrate flux can be estimated by $J_{v}=K_{H}(\partial N / \partial z)$.

\section{Results}

\subsection{Physical and biogeochemical setting of the NSCS shelf during the spring-summer}

The temperature vs. salinity diagram revealed a large change in hydrography during the three cruises (Fig. 2). There was a regional increase in temperature over the shelf from April to June (Fig. 3a1-a3), along with an increase in wind strength (with a regional shift to upwelling favorable wind after the May, data not shown). The riverine input was clearly evidenced with low-salinity waters in all three cruises (Fig. 2). Spatially, there was a large area of low salinity in the coastal water, west of the PRE (Fig. 3b1-b3), leading to a strong salinity front in the inner shelf. The plume water was mostly on the shore side of the front when the river outflow was westward along the shore. The shore side of the front was defined by a salinity of $<26$ (the nearshore boundary of the plume; Wong et al., 2003), with the sea side of the front by a salinity of $>32$ (the offshore boundary of the plume; Ou et al., 2007). The frontal zone is thus located in between the nearshore and offshore boundaries of the river plume (Fig. 1).

In the coastal water, west of the PRE, there was an intense chlorophyll $a$ bloom (Chl- $a>5 \mu \mathrm{gL}^{-1}$ ) on the shore side of the front during all the three cruises (Fig. 3c1-c3), although the surface temperature of the bloom area increased from $\sim 22^{\circ} \mathrm{C}$ in April, to $\sim 26^{\circ} \mathrm{C}$ in May and to $\sim 31^{\circ} \mathrm{C}$ in June. The surface distributions of nitrate, silicate and phosphate 

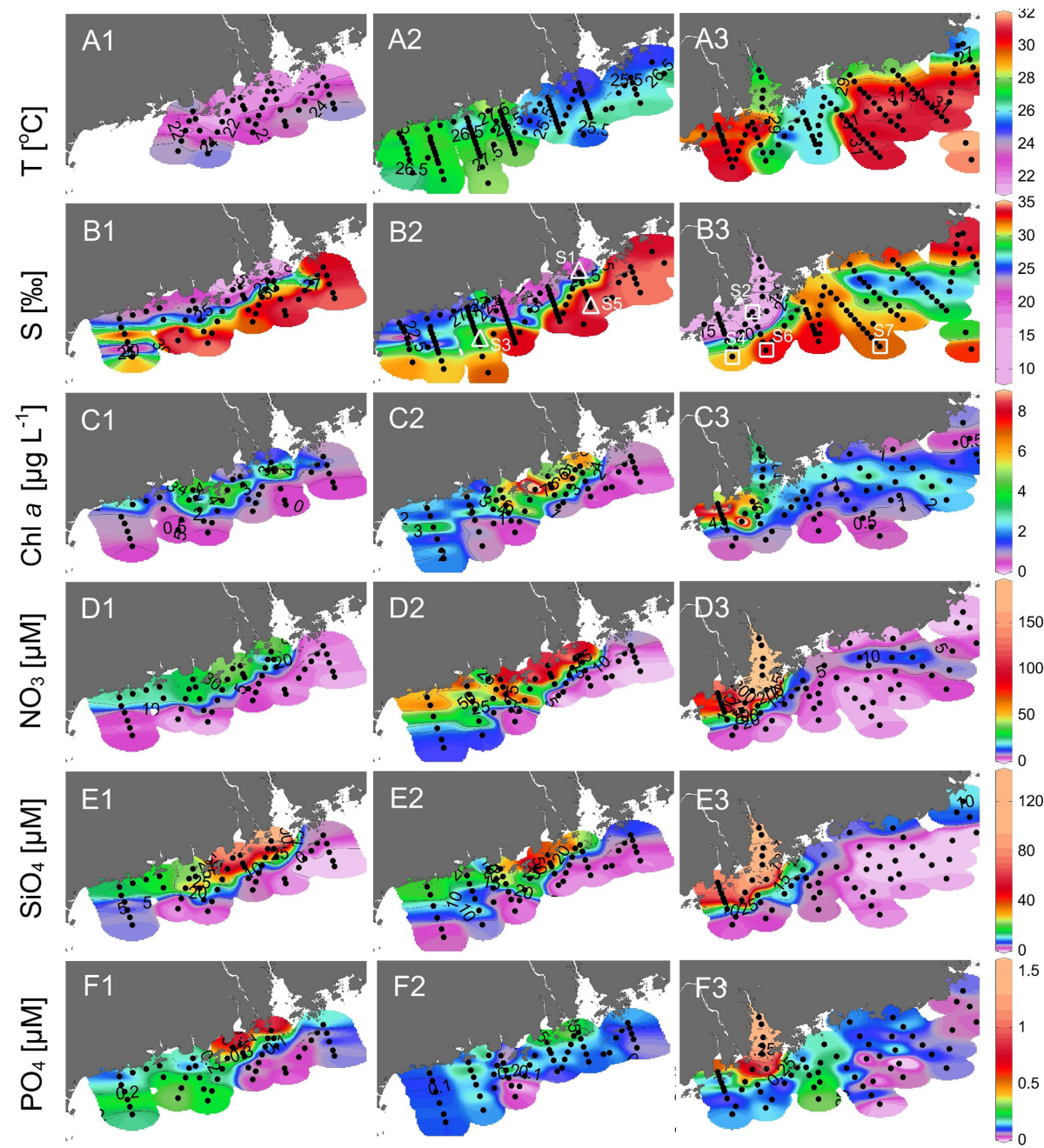

Figure 3. Surface distributions of (a1)-(a3) temperature, (b1)-(b3) salinity, (c1)-(c3) chlorophyll $a$, (d1) $-(\mathbf{d 3})$ nitrate, (e1)-(e3) silicate and (f1)-(f3) phosphate in the NSCS during April, May and June 2016. Small dots are the data points; open triangles and squares in (b2)-(b3) show the positions of $\mathrm{S} 1-\mathrm{S} 7$.

generally follow that of salinity for all the three cruises with much higher concentrations on the shore side of the front than at the sea side of the front (Fig. 3d and f). Interestingly, the surface low salinity tongue in the coastal water east of the PRE (generated by eastward plume dispersion) was cut off by another water mass of low temperature but high salinity during June (Fig. 3a3 and b3). This colder and saltier water presumably should come from the subsurface via coastal upwelling, which was further supported by its higher phosphate concentration but lower $\mathrm{N} / \mathrm{P}$ ratio compared to the ambient waters (Fig. $3 \mathrm{~d} 3$ and $\mathrm{f} 3$ ).

There were substantial vertical changes in temperature, salinity and chlorophyll $a$ while crossing the salinity front (Fig. 4a-c) from the estuary to the shelf (Section A). The surface front was located in the inner shelf with the subsurface frontal zone descending to the bottom of the estuary mouth (Fig. 4a). Vertical distributions of nutrients generally followed those of salinity in the PRE with higher surface concentrations, whereas there was large drawdown of nutrients on the shore side of the front when approaching the edge of the river plume (Fig. 4d-f), corresponding to a fast decrease in N/P ratio from the shore side of the front to the frontal zone. The dominant size class shifted from micro- to picocells while crossing the salinity front from the shore in Section B for both the May and June cruises (Fig. 5). Variations in the percentages of micro- and nanocells in sections $\mathrm{C}$ and $\mathrm{D}$ were due to a spatial change in the frontal zone (Fig. 5).

\subsection{Variations of phytoplankton nutrient limitation over the NSCS shelf}

Surface water properties of the incubation stations were summarized in Table 1. The highest concentrations of nutrients and chlorophyll $a$ were in S1 and S2 on the shore side of the front where micro- and nanocells dominated. A P de- 

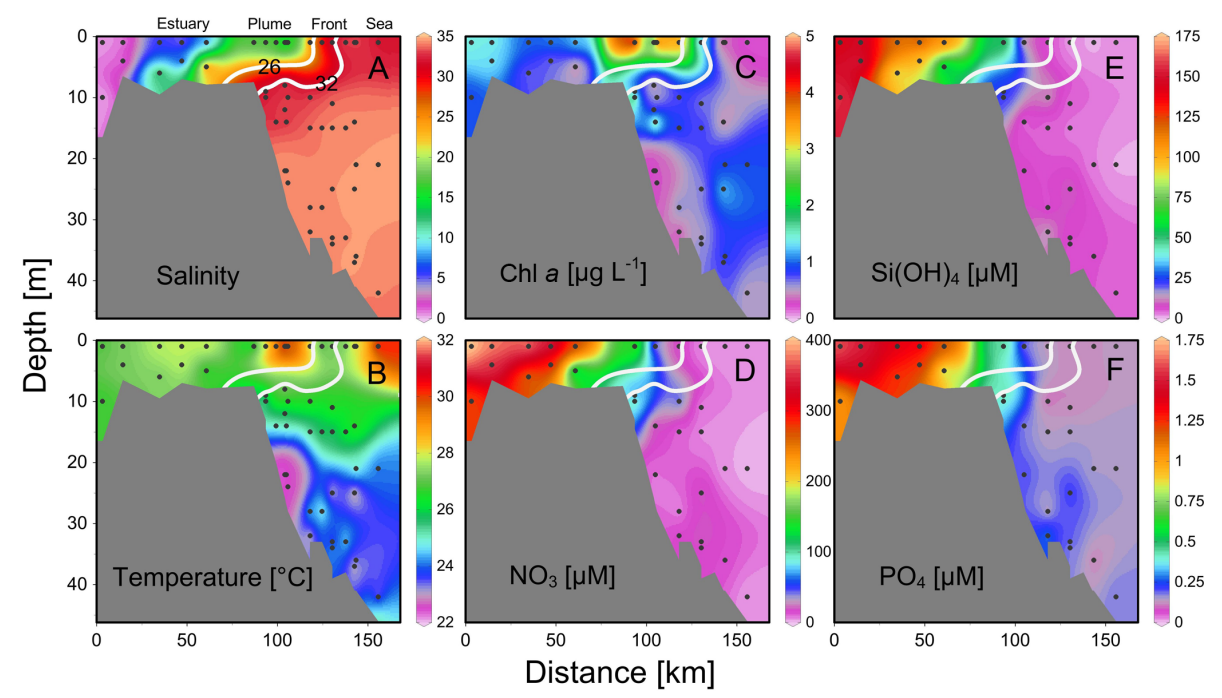

Figure 4. Vertical distributions of (a) salinity, (b) temperature, (c) chlorophyll $a$ and (d) nitrate, (e) silicate and (f) phosphate across the front of the estuary to the sea. Location of the section during the three cruises is in Fig. 1. Two white lines are salinity levels of 26 and 32 for nearshore and offshore boundaries of the plume (see text for detail).

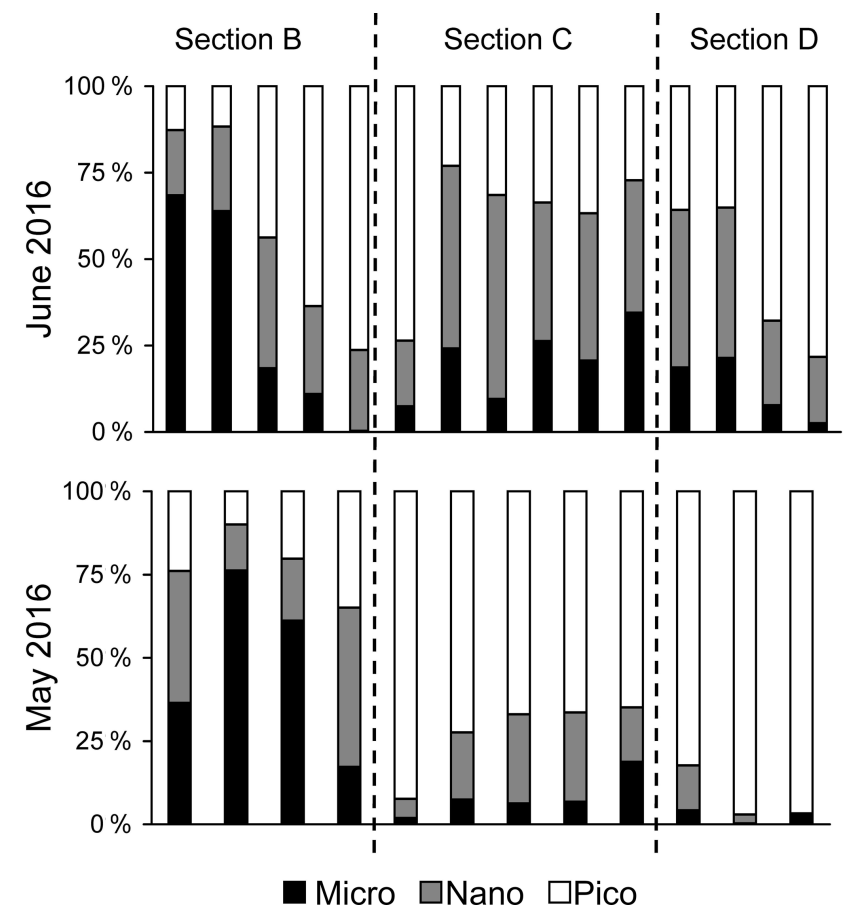

Figure 5. Comparisons of size-fractionation chlorophyll $a$ for sections B, C and D between May and June 2016.

ficiency of the plume water can be inferred from the high $\mathrm{N} / \mathrm{P}$ ratios there. There was higher salinity $(\sim 30)$ but lower chlorophyll $a\left(\sim 1 \mu \mathrm{gL}^{-1}\right)$ in S3 and S4 at the frontal zone, which should reflect a reduced impact of the river plume. The surface waters of S5, S6 and S7 on the sea side of the front were dominated by picophytoplankton and showed the typi- cal characteristics of the open NSCS with low nutrients and chlorophyll $a$ but high salinity.

Phytoplankton total chlorophyll $a$ on the shore side of the front (S1 and S2) and at the frontal zone (S3 and S4) showed responses to $\mathrm{P}$ addition but not $\mathrm{N}$ addition, suggesting $\mathrm{P}$ limitation in these waters (Fig. 6a1-d1). Results of nutrient variations during the incubations confirmed that $\mathrm{N}$ consumption in these stations was significantly enhanced by the addition of $\mathrm{P}$ (Fig. 6a2-d2), but $\mathrm{P}$ consumption was not stimulated by the addition of $\mathrm{N}$ (Fig. 6a3-d3). In contrast, phytoplankton nutrient limitation varied substantially at S5, S6 and S7 on the sea side of the front (Fig. 6e1-g1). Total chlorophyll showed no response to $\mathrm{N}$ addition, $\mathrm{P}$ addition and $\mathrm{N}$-plus-P addition at S5 (Fig. 6e1), which should suggest a relief of the phytoplankton community from $\mathrm{N}$ and $\mathrm{P}$ stresses there. Indeed, there was no difference in nutrient consumption between $\mathrm{N}$ and $\mathrm{P}$ additions (Fig. 6e2 and 6E3) There was an $\mathrm{N}$ limitation of phytoplankton at S6, as the total chlorophyll $a$ increased with $\mathrm{N}$ addition but not with $\mathrm{P}$ addition (Fig. 6f1), which was consistent with its low $\mathrm{N}+\mathrm{N}$ concentration of $<0.5 \mu \mathrm{M}$ at the surface (Table 1). The $\mathrm{N}$ limitation of $\mathrm{S} 6$ was further supported by nutrient data with enhanced $\mathrm{P}$ consumption by $\mathrm{N}$ addition in Fig. 6f3 (but no difference in $\mathrm{N}$ consumption by $\mathrm{P}$ addition, Fig. 6f2). Phytoplankton growth was $\mathrm{P}$ limited at S7 during the first day of incubation (Fig. $6 \mathrm{~g} 1$ and g2), but it became colimited by both $\mathrm{N}$ and $\mathrm{P}$ during the second day of incubation (Fig. $6 \mathrm{~g} 1$ ) as the substrate $\mathrm{N}$ was running out (Fig. 6g2). This station (S7) was on the shelf edge, far away from the frontal zone, but was influenced by the eastward extension of the plume as indicated by its relatively low surface salinity.

Interestingly, the response of phytoplankton total chlorophyll $a$ to nutrient treatment was mostly mediated by micro- 

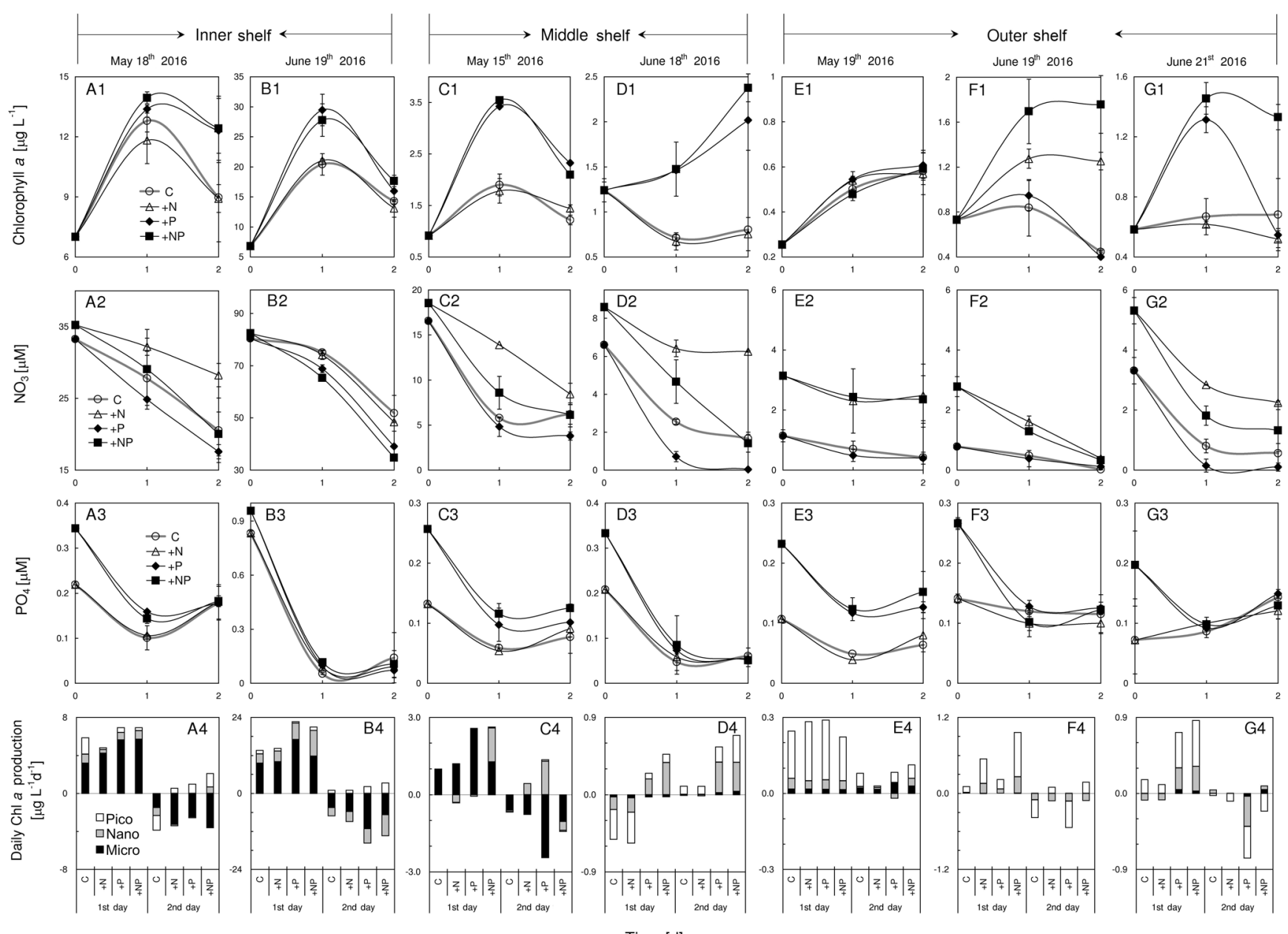

Figure 6. Responses of total chlorophyll $a$, nitrate, phosphate and size-fractionated daily chlorophyll $a$ production rate of the surface water to various nutrient enrichments at (a1)-(a4) S1, (b1)-(b4) S2, (c1)-(c4) S3, (d1)-(d4) S4, (e1)-(e4) S5, (f1)-(f4) S6 and (g1)-(g4) S7 during May and June 2016. Station locations are in Fig. 1 with the initial conditions in Table 1; treatments include control $(\mathrm{C})$, nitrogen alone $(+\mathrm{N})$, phosphorus alone $(+\mathrm{P})$ and nitrogen plus phosphorus $(+\mathrm{NP})$, respectively; chlorophyll $a$ size fractionations of the initial waters for these stations are shown in Table 1.

cells at stations S1, S2 and S3, where high nutrient concentrations and N/P ratios were found (Fig. 6a4-c4). In contrast, for stations S5, S6 and S7 on the sea side of the front, the change in total phytoplankton chlorophyll $a$ at the surface layer was largely contributed to by picophytoplankton (Fig. 6d4-g4). This result is consistent with the contention that larger phytoplankton grows faster than small cells under nutrient-replete conditions.

\subsection{Responses of surface phytoplankton to the addition of plume water}

We considered the mixing of both nutrients and phytoplankton between the plume water and the local seawater at the frontal zone, given the relatively short distance of these two waters. The result of mixing experiments between the surface waters of S2 and S4 was shown in Fig. 7. The total chlorophyll $a$ of the mixed phytoplankton community was proportional to the amount of PW (the surface water of S2) (Fig. 7a), as the PW had more chlorophyll $a$ than S4 (Table 1). Given a $P$ limitation of the mixed phytoplankton community, the substrate phosphate was quickly consumed within the first day of incubation (Fig. 7b). The three phytoplankton size classes showed distinct responses to the ascending PW percentage during the first day of incubation (Fig. 7c and d). There was a linear increase in the daily chlorophyll $a$ production rate of microcells with the percentage of PW $\left(r^{2}=0.9, p<0.01\right)$, whereas the production rate of nanocells first increased with the PW percentage from 0 to $50 \%$ and then remained relatively stable from 50 to $100 \%$. Apart from both micro- and nanocells, picophytoplankton reached the maximal production rates at $50-75 \%$ of PW treatments. The responses of net growth rates to various PW treatments (Fig. 7d) were slightly different from those of 

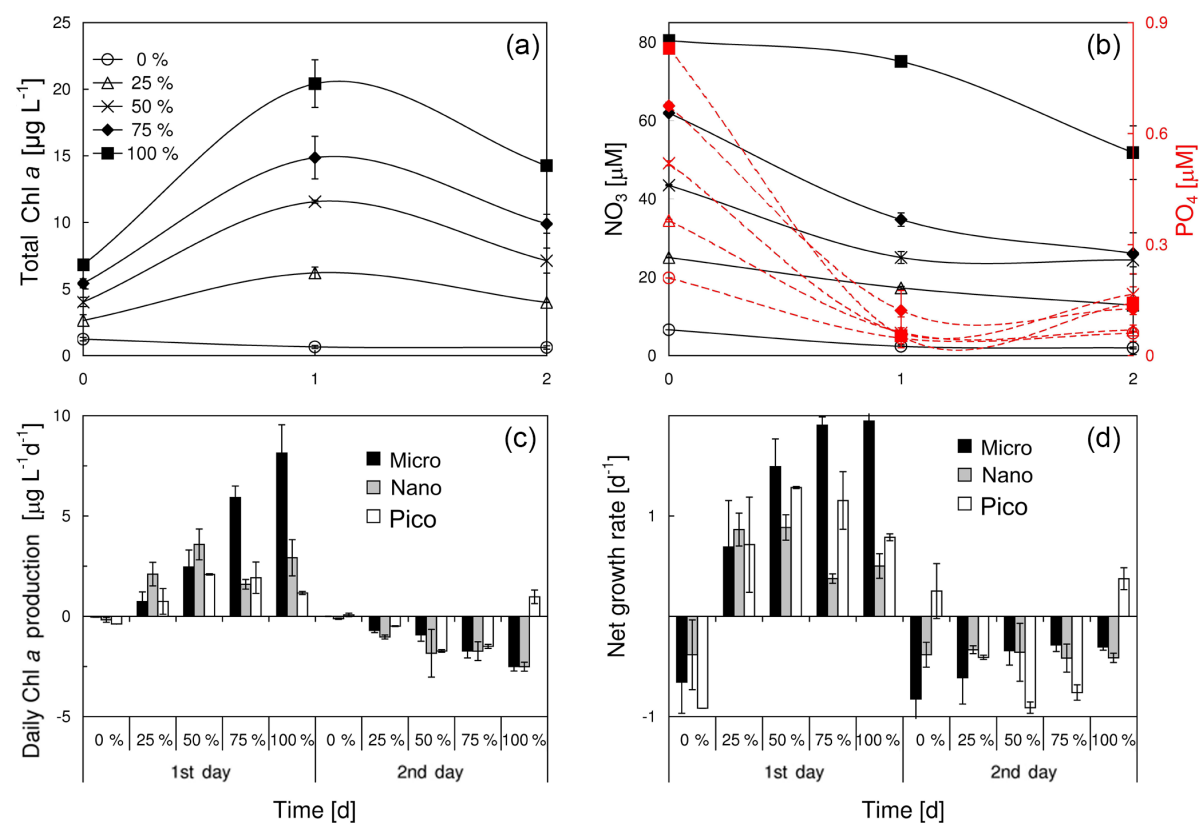

Figure 7. Responses of (a) total chlorophyll $a$, (b) nitrate and phosphate, (c) size-fractionated rate of daily chlorophyll $a$ production and (d) size-fractionated net growth rate of the surface water at S4 to a varying percentage of plume water from S2. The experiment was started on 19 June 2016.

the chlorophyll $a$ production rates (Fig. 7c). The net growth rate of microphytoplankton increased with the PW percentage before becoming saturated at $75-100 \%$ PW. Picophytoplankton showed a higher net growth rate but lower daily chlorophyll $a$ production rate than nanophytoplankton during the first day of incubation for $50-100 \%$ PW treatments. As the phosphate was running out (Fig. 7b), there were negative net growth rates for all the size classes during the second day of incubation (Fig. 7d).

The chlorophyll $a$ biomass, as well as the daily chlorophyll $a$ production rate, was substantially enhanced by the addition of FPW at S6, S7 and S8 (Fig. 8a1-c1), regardless of the type of nutrient limitation the surface phytoplankton originally experienced. This should be expected as the plume water had far more nutrients than the local waters on the sea side of the front (Fig. 8a2-c2 and a3-c3). The small percentage of FPW addition (12.5\%) was to ensure that the initial chlorophyll $a$ concentration after FPW dilution is comparable with that of the control experiment (thus, the initial chlorophyll $a$ will neither be promoted by the addition nor be diluted too much by the addition). The response of the phytoplankton community to FPW was largely determined by nano- and picocells at these stations (Fig. 8a4-c4). Interestingly, although the amount of the raw plume water (PW) added was only $12.5 \%$, it contributed about half of the chlorophyll biomass to the mixed community for S6, which was due to the high chlorophyll $a$ concentration of PW (Table 1). That is why a stronger response of phytoplankton chlorophyll $a$ to PW than to FPW was observed (Fig. 8a1).

\subsection{Responses of surface phytoplankton to the addition of bottom waters}

The addition of FBW increased the total chlorophyll $a$ of S2, which was largely contributed by microcells (Fig. 9a1 and a4). At this station, the inclusion of FBW (a lower N/P ratio of $\sim 28$ ) reduced the $\mathrm{N}$ concentration (Fig. 9a2) but not the $\mathrm{P}$ concentration (Fig. 9a3), leading to a lower N/P ratio of the surface water $(\sim 87)$ and thus the $\mathrm{P}$ stress of surface phytoplankton. We found no difference in chlorophyll responses to FBW and $\mathrm{BW}$ at $\mathrm{S} 2$, which could be due to the low chlorophyll $a$ of BW. Interestingly, there was a net loss of phytoplankton chlorophyll $a$ with time at S4, which was not affected by the FBW treatment (Fig. 9b1). This is because nitrate and phosphate concentrations of the surface water were similar to those of the FBW, although there was a 9-fold increase in silicate in the FBW (Table 1). The elevated silicate after FBW treatment did not stimulate a diatom growth given the sparsity of microcells in the surface water there. The addition of BW substantially decreased the total chlorophyll $a$ (Fig. 9b1), although the consumptions of $\mathrm{N}$ and $\mathrm{P}$ were similar to those of the control (Fig. 9b2 and b3). Both the additions of FBW and BW were found to stimulate phytoplankton growth at S6 (Fig. 9c1) due to elevated N concentration (Fig. 9b2), whereas the magnitude of promotion by FBW is much higher than that by BW (Fig. 9c1). There was no significant difference found in growth responses of phytoplankton to FBW and BW treatments at S7 (Fig. 9d1). This is because the BW of S7 was from the depth of $109 \mathrm{~m}$ with 

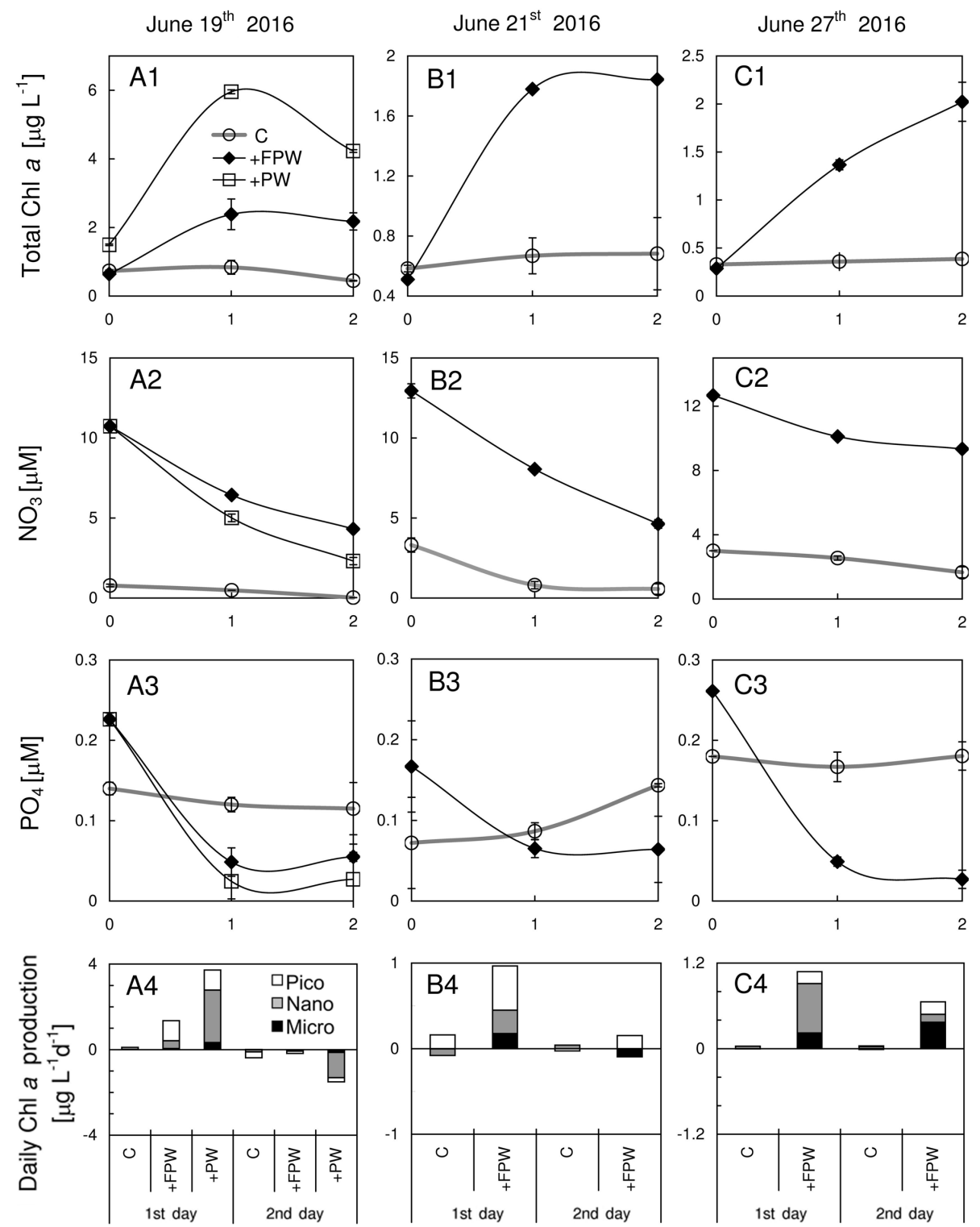

Time $[\mathrm{d}]$

Figure 8. Responses of total chlorophyll $a$, nitrate, phosphate and size-fractionated rate of daily chlorophyll $a$ production in the surface water to the addition of plume water at (a1)-(a4) S6, (b1)-(b4) S7 and (c1)-(c4) S8. PW is the plume water with FPW the filtered plume water.

higher nutrients but negligible chlorophyll $a$ compared to the surface water (Fig. 9d1-d3).

\section{Discussion}

The persistent salinity front we observed from April to May of 2016 was a plume-induced buoyant front (e.g., Ou et al., 2007), which could appear when the freshwater discharge was much stronger than the tidal effect (Garvine and Monk, 1974). While governed by buoyancy, planetary rotation and wind forcing (Wong et al., 2003), the impact of the plume front on the coastal NSCS was large, due to the low salin- ity water spreading westward and eastward over the large area of the shelf. A chlorophyll bloom on the shore side of the front was a direct response of phytoplankton to the river plume (Harrison et al., 2008), as nutrient replenishment from the subsurface could be restricted by the salinity front with a persistent stratification at the frontal zone. In contrast, there was an intense upwelling found near the coastal water east of the PRE, which could be due to an intensified cross-isobath transport of the bottom boundary layer driven by an amplified alongshore current (Gan et al., 2009). Therefore, the frontal system was affected by both the river plume and coastal upwelling during the spring-summer of 2016. 

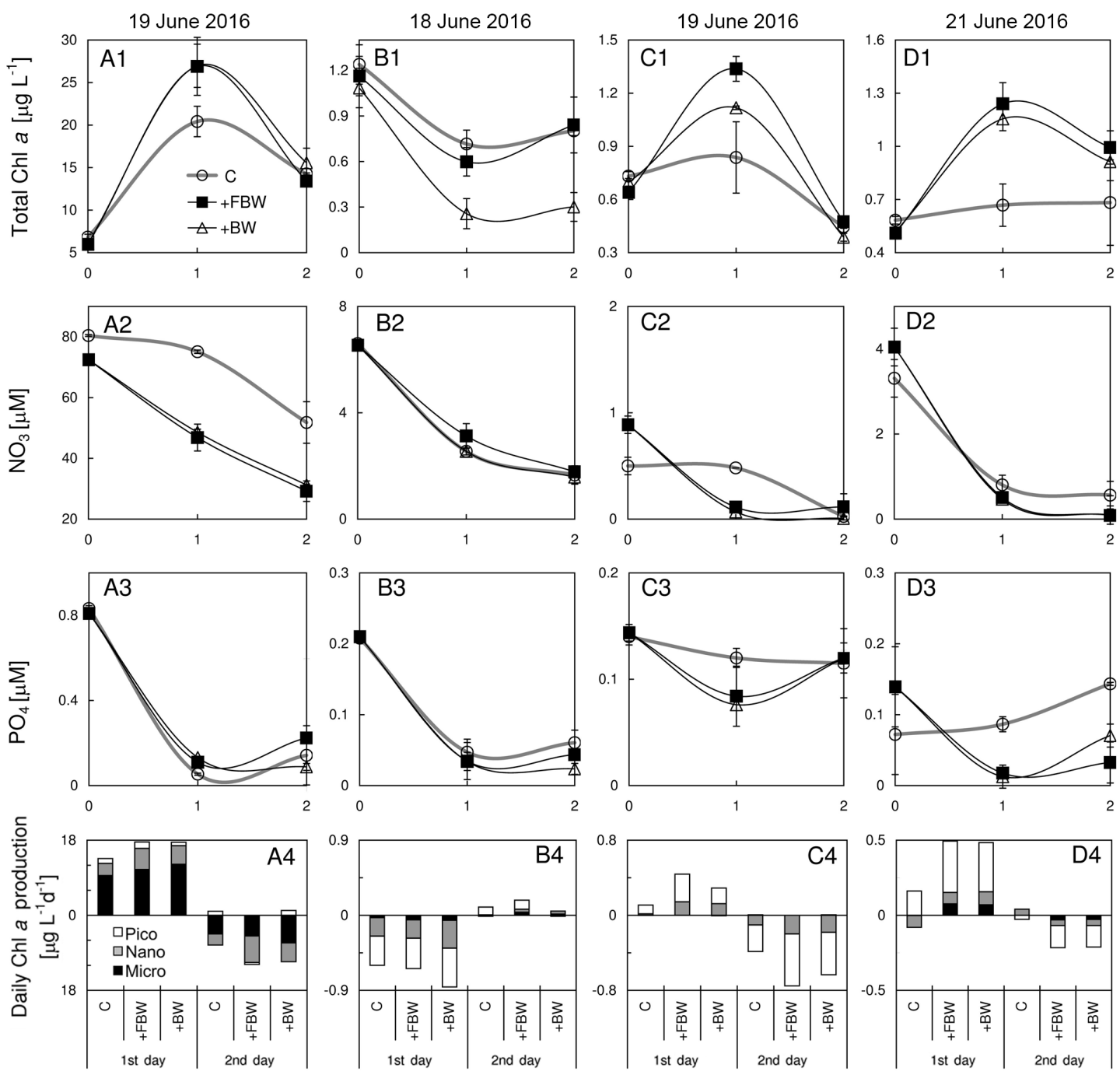

Time [d]

Figure 9. Responses of total chlorophyll $a$, nitrate, phosphate and size-fractionated rate of daily chlorophyll $a$ production in the surface water to the addition of local bottom waters at stations (a1)-(a4) S2, (b1)-(b4) S4, (c1)-(c4) S6, and (d1)-(d4) S7 during June 2016. BW is bottom water and FBW is filtered bottom water.

Phytoplankton growth over the shore side of the front was essentially $\mathrm{P}$ limited, which is consistent with previous findings (Zhang et al., 1999; Yin et al., 2001). Phytoplankton P stress here is a physiological response to the P deficiency of the river plume due to the stoichiometric lack of $\mathrm{P}$ relative to N (Moore et al., 2013). However, we found a spatial difference in phytoplankton physiology on the sea side of the front, where there was less influence from the river plume from the perspective of salinity. Phytoplankton growth over the sea side of the front, dominated by small picocells, could be $\mathrm{P}$ limited, $\mathrm{N}$ limited or not limited by $\mathrm{N}$ and $\mathrm{P}$. There was no evidence of Si limitation since microcell was not stimulated by the filtered bottom water with a much higher silicate concentration. The spatial difference in phytoplankton physiology is consistent with the nutrient variation in the devel- oping plume front, which should be regulated by both biological uptake and physical dynamics (Gan et al., 2014).

A balance between horizontal advection and vertical mixing can be approximately maintained at the seaward front by an Ekman straining mechanism (Fong and Geyer, 2001) with salinity gradients created by cross-shore Ekman current but destroyed by vertical mixing. Based on the hydrographic data, we can estimate a horizontal entrainment rate $U_{\mathrm{e}}$ of $0.5-1.0 \times 10^{-5} \mathrm{~m} \mathrm{~s}^{-1}$ and a vertical diffusivity $K_{H}$ of $0.8-1.7 \times 10^{-4} \mathrm{~m}^{2} \mathrm{~s}^{-1}$ across the frontal boundary, which are comparable to those previously found over the NSCS shelf (St. Laurent, 2008; Li et al., 2016). Horizontal nitrate flux to the sea side of the front is thus $0.2-3.6 \mathrm{mmolN} \mathrm{m}^{-2} \mathrm{~d}^{-1}$. If we assume the same $K_{H}$ for the sea side of the front, we can also roughly estimate a vertical nitrate diffusive flux of 
$0.6-4.7 \mathrm{mmol} \mathrm{N} \mathrm{m}^{-2} \mathrm{~d}^{-1}$, which is of the same order of magnitude as the horizontal nutrient fluxes. Therefore, the varying nutrient supply driven by physical dynamics, including cross-frontal advection and vertical mixing, might be responsible for the variability in phytoplankton physiology on the sea side of the front.

The phytoplankton community at the frontal zone during our mixing experiment between $\mathrm{S} 2$ and $\mathrm{S} 4$ should consist of coastal phytoplankton species, as the salinity of 6.630.7 is higher than the lethal level of $\sim 5$ for most estuarine phytoplankton due to osmotic pressure (Kies, 1997; Flöder et al., 2010). Coastal phytoplankton would generally tolerate a much larger range of salinity than estuarine and oceanic species (e.g., Brand, 1984). Therefore, the salinity effect could be less important for the change in chlorophyll $a$ concentration during our experiments. The observed chlorophyll $a$ response of the mixed community to the PW treatments at the frontal zone should reflect the combined effects of varying nutrient concentrations and phytoplankton populations induced by the addition of PW. The relative contributions of these two factors were roughly assessed at station S6 with the additions of a small percentage (12.5\%) of FPW and PW, respectively (Fig. 8a1-a4). Due to a large increase in initial nutrient concentrations by the addition of FPW, phytoplankton growth was significantly enhanced compared to that of the control experiment with a similar initial chlorophyll $a$ concentration. A stronger chlorophyll $a$ response to the PW treatment than to the FPW treatment at S6, however, was caused by an enhanced initial phytoplankton population by PW, which also resulted in a larger nutrient drawdown during the PW addition experiment (Fig. 8a2-a3).

The mixing of plume water at the frontal zone was found to directly stimulate microphytoplankton growth, while a community $\mathrm{P}$ limitation was still prevailing. Although the growths of nano- and picocells were improved by low percentages of PW $(<50 \%)$, they were inhibited by high percentages of PW (>50\%). The finding is consistent with the different nutrient uptake kinetics of the three phytoplankton size classes (Finkel et al., 2010). Microphytoplankton generally has a larger half-saturation constant for nutrient uptake than nano- and picophytoplankton (Cermeno et al., 2005; Litchman et al., 2007). Therefore, small phytoplankton (nano- and picocells) could become saturated with the ascending nutrients before microphytoplankton did. At the frontal zone, nanophytoplankton growth even far exceeded microphytoplankton at a low percentage of PW $(<50 \%)$, which could explain the enhanced biomass percentage of nanocells at the frontal zone. The difference in chlorophyll $a$ production and net growth rate among three phytoplankton size classes could also be related to the change in seawater $\mathrm{N} / \mathrm{P}$ ratio. It has been known that the optimal $\mathrm{N} / \mathrm{P}$ ratio of phytoplankton may vary substantially among different phytoplankton species (Geider and Roche, 2002) and may increase with ascending $\mathrm{N} / \mathrm{P}$ of the available nutrients (Hillebrand et al., 2013). Faster-growing small phytoplank- ton, such as cyanobacteria, often has a lower optimal $\mathrm{N}: \mathrm{P}$ ratio leading to its domination in eutrophic waters with lower N/P ratios (Vrede et al., 2009; Hillebrand et al., 2013), which is consistent with our finding of reduced net growth rates of small phytoplankton at higher percentages of PW treatments (higher $\mathrm{N} / \mathrm{P}$ ratios).

In contrast to the shore side of the front which has a sharp decrease in nutrients at depths, the bottom water on the sea side of the front showed much higher nutrient concentrations (but lower N/P ratios) than the surface water, which was due to the intrusion of the deep water (Gan et al., 2014). Thus, after vertical mixing or upwelling, surface nutrient concentrations should decrease on the shore side of the front but increase on the sea side of the front. The final consequence of vertical mixing on both sides of the front was to alter the $\mathrm{N} / \mathrm{P}$ ratio of surface water closer to the Redfield ratio of 16 and thus improve the growth of phytoplankton. Indeed, phytoplankton growth was substantially promoted by the FBW addition at S6 (Fig. 9c1), as the $\mathrm{N}$ stress of phytoplankton was relieved by the FBW with higher nitrate concentration (Fig. 9c2) and N/P ratio (Fig. 9c3). At station S7, both FBW and BW additions increased surface phytoplankton growth (Fig. 9d1), which could be attributed to reduced $\mathrm{P}$ stress in phytoplankton in response to a lower N/P ratio $(\sim 29)$ of the surface water. While microplankton growth was slightly stimulated by the BW addition, our results on the sea side of the front did not show a shift in the phytoplankton community from pico- to microcells in response to upwelled nutrients from deepwater additions found in the western South China Sea (Cui et al., 2016) and in the open ocean (McAndrew et al., 2007; Mahaffey et al., 2012).

In addition to nutrient stresses by varying nutrient concentrations and ratios, phytoplankton growth at the frontal zone should also be influenced by other factors such as the change in grazing pressure ( $\mathrm{Li}$ et al., 2012). There was indeed evidence of enhanced grazing activity at stations S4 and S6 when comparing incubation results of the filtered bottom water $(\mathrm{BW})$ to those without filtration $(\mathrm{FBW})$. We found a reduced phytoplankton growth with the addition of BW compared to that of FBW at both S4 and S6 (Fig. 9b1 and 9c1). The finding should indicate an intense grazing activity of BW since $\mathrm{N}$ and $\mathrm{P}$ consumption was very similar between $\mathrm{BW}$ and FBW treatments at these stations (Fig. 9b and c). Therefore, further study of grazing impact of zooplankton on various sizes of phytoplankton and subsequent biomass accumulation at the frontal zone of the NSCS shelf may be a future research priority. Since we have only focused on phytoplankton physiology of the surface layer, the future study may also need to address the response of the subsurface phytoplankton community to the frontal dynamics over the shelf, since both the light field and nutrient conditions may vary substantially at the subsurface layer across the salinity front. 


\section{Conclusions}

Overall, the importance of physical-biological interaction in driving patterns of phytoplankton physiology and sizefractionated growths within a strong plume-induced salinity front over the NSCS shelf was investigated with intense field measurements and shipboard incubation experiments during April-June 2016. The current study suggested that variability in phytoplankton nutrient limitation and size-fractionated growth on the shore side, the sea side and the frontal zone of the shelf sea frontal system could be attributed to varying nutrient supplies driven by physical dynamics in the frontal system. While the impact of the river plume was to directly increase the growth rates of all the three phytoplankton size classes, both nano- and picocells could become saturated with a high percentage of plume water at the frontal zone. Vertical mixing or upwelling was found to substantially improve surface phytoplankton growth on both sides of the front by altering the nutrient concentrations and ratios. These results are important for a better understanding of the physical control of coastal ecosystem dynamics in the NSCS shelf sea.

Data availability. Data supporting the findings of this study are available within the article or are available from the corresponding author, Qian P. Li, upon request.

Competing interests. The authors declare that they have no conflict of interest.

Acknowledgements. We thank the captain and the staff of $\mathrm{R} / \mathrm{V}$ Zhanjiang Kediao for help during the cruises. Jie $\mathrm{Xu}$ and Dongxiao Wang were acknowledged for cruise assistants. This work is supported by the National Key Research and Development Program of China (2016YFC0301202) and the National Natural Science Foundation of China (41676108, 41706181).

Edited by: Emilio Marañón

Reviewed by: three anonymous referees

\section{References}

Acha, E. M., Mianzan, H. W., Cuerrero, R. A., Favero, M., and Bava, J.: Marine fronts at the continental shelves of austral South America: Physical and ecological processes, J. Marine Syst., 44, 83-105, 2004.

Alexander, H., Rouco, M., Haley, S. T., Wilson S. T., Karl D. M., and Dyhrman S. T: Functional group-specific traits drive phytoplankton dynamics in the oligotrophic ocean, P. Natl. Acad. Sci. USA, 112, 5972-5979, 2015.

Brand, L. E.: The salinity tolerance of fourty-six marine phytoplankton isolates, Estuar. Coast. Shelf S., 18, 543-556, 1984.
Cai, W., Dai, M., Wang, Y., Zhai W., Huang T., Chen S., Zhang F., Chen Z., and Wang Z.: The biogeochemistry of inorganic carbon and nutrients in the Pearl River estuary and the adjacent Northern South China Sea, Cont. Shelf Res., 24, 1301-1319, 2004.

Cermeño P, Maranón, E., Rodríguez, J. and Fernández E.: Largesized phytoplankton sustain higher carbon specific photosynthesis than smaller cells in a coastal eutrophic ecosystem, Mar. Ecol.-Prog. Ser., 297, 51-60, 2005.

Chen, Y. L. L., Chen, H. Y., Karl, D. M., and Takahashi, M.: Nitrogen modulates phytoplankton growth in spring in the South China Sea, Cont. Shelf Res., 24, 527-541, 2004.

Cui, D., Wang, J., and Tan, L.: Response of phytoplankton community structure and size-fractionated chlorophyll $a$ in an upwelling simulation experiment in the western South China Sea, J. Ocean Univ. China, 15, 835-840, 2016.

Dagg, M. J., Benner, R., Lohrenz, S. E., and Lawrence, D.: Transformation of dissolved and particulate materials on continental shelves influenced by large rivers: plume processes, Cont. Shelf Res., 24, 833-858, 2004.

Dong, L., Su, J., Wong, L., Cao, Z., and Chen, J.: Seasonal variation and dynamics of the Pearl River plume, Cont. Shelf Res., 24, 1761-1777, 2004.

Finkel, Z. V., Beardall, J., Flynn, K. J., Quigg, A., Rees, T. A. V., and Raven, J. A.: Phytoplankton in a changing world: cell size and elemental stoichiometry, J. Plankton Res., 32, 119-137, 2010.

Flöder, S., Jaschinski, S., Wells, G., and Burns, C. W.: Dominance and compensatory growth in phytoplankton communities under salinity stress, J. Exp. Mar. Biol. Ecol., 395, 223-231, 2010.

Fong, D. A. and Geyer, W. R.: Response of a river plume during an upwelling favorable wind event, J. Geophys. Res., 106, 10671084, 2001.

Gan, J., Cheung, A., Guo, X., and Li, L.: Intensified upwelling over a widened shelf in the northeastern South China Sea, J. Geophys. Res., 114, C09019, https://doi.org/10.1029/2007JC004660, 2009.

Gan, J., Lu, Z., Cheung, A., Dai, M., Liang, L., Harrison, P. J., and Zhao, X.: Assessing ecosystem response to phosphorus and nitrogen limitation in the Pearl River plume using the Regional Ocean Modeling System (ROMS), J. Geophys. Res., 119, 88588877, https://doi.org/10.1002/2014JC009951, 2014.

Garvine, R. W. and Monk, J. D.: Frontal structure of a river plume, J. Geophys. Res., 79, 2251-2259, 1974.

Geider, R. and Roche, J.: Redfield revisited: Variability of C : N : P in marine microalgae and its biochemical basis, Eur. J. Phycol., 37, 1-17, 2002.

Harrison, P. J., Yin, K., Lee, J. H. W., Gan, J., and Liu, H.: Physicalbiological coupling in the Pearl River Estuary, Cont. Shelf Res., 28, 1405-1415, 2008.

Hillebrand, H., Steinert, G., Boersma, M., Malzahn, A., Meunier, C., Plum, C., and Ptacnik, R.: Goldman revisited: Fastergrowing phytoplankton has lower $\mathrm{N}: \mathrm{P}$ and lower stoichiometric flexibility, Limnol. Oceanogr., 58, 2076-2088, 2013.

Horner-Devine, A. R., Hetland, R. D., and Macdonald, D. G.: Mixing and transport in coastal river plumes, Annu. Rev. Fluid Mech., 47, 569-594, 2015.

Kies, K.: Distribution, biomass and production of planktonic and benthic algae in the Elbe Estuary, Limnologica, 27, 55-64, 1997. 
Knap, A., Michaels, A., Close, A., Ducklow, H., and Dickson, A.: Protocols for the Joint Global Ocean Flux Study (JGOFS) Core Measurements, JGOFS Report No 19, 170 pp., 1996.

Li, Q. P., Franks, P. J. S., Ohman, M. D., and Landry, M. R.: Enhanced nitrate fluxes and biological processes at a frontal zone in the Southern California current system, J. Plankton Res., 34, 790-801, 2012.

Li, Q. P., Dong, Y., and Wang, Y.: Phytoplankton dynamics driven by vertical nutrient fluxes during the spring inter-monsoon period in the northeastern South China Sea, Biogeosciences, 13, 455466, https://doi.org/10.5194/bg-13-455-2016, 2016.

Litchman E, Klausmeier, C. A., Schofield, O. M., and Falkowski, P. G.: The role of functional traits and tradeoffs in structuring phytoplankton communities: scaling from cellular to ecosystem level, Ecol. Lett., 10, 1170-1181, 2007.

Liu, K., Chao, S., Shaw, P., Gong, G., Chen, C., and Tang, T.: Monsoon-forced chlorophyll distribution and primary production in the South China Sea: observations and a numerical study, Deep-Sea Res. Pt. I, 49, 1387-1412, 2002.

Lohrenz, S. E., Redalje, D., Cai, W., Acker, J., and Dagg, M.: A retrospective analysis of nutrients and phytoplankton productivity in the Mississippi River Plume, Cont. Shelf Res., 28, 1466-1475, 2008.

Mahaffey, C., Björkman, K. M., and Karl, D. M.: Phytoplankton response to deep seawater nutrient additions in the North Pacific Subtropical Gyre, Mar. Ecol.-Prog. Ser., 460, 13-34, 2012.

Marañón, E.: Cell size as a key determinant of phytoplankton metabolism and community structure, Annu. Rev. Mar. Sci., 7, 241-264, 2015.

Marañón, E., Cermeño, P., Latasa, M., and Tad, R. D.: Temperature, resources, and phytoplankton size structure in the ocean, Limnol. Oceanogr., 57, 1266-1278, 2012.

Marañón, E., Cermeño, P., Latasa, M., and Tad, R. D.: Resource supply alone explains the variability of marine phytoplankton size structure, Limnol. Oceanogr., 60, 1848-1854, 2015.

McAndrew, P. M., Björkman, K. M., Church, M. J., Morris, P. J., Jachowski, N., Williams, P. J. le B., and Karl, D .M.: Metabolic response of oligotrophic plankto communities to deep water nutrient enrichment, Mar. Ecol.-Prog. Ser., 332, 63-75, 2007.

Moore, C. M., Mills, M. M., Arrigo, K. R., Berman-Frank, I., Bopp, L., Boyd, P. W., Galbraith, E. D., Geider, R. J., Guieu, C., Jaccard, S. L., Jickells, T. D., La Roche, J., Lenton, T. M., Mahowald, N. M., Marañón, E., Marinov, I., Moore, J. K., Nakatsuka, T., Oschlies, A., Saito, M. A., Thingstad, T. F., Tsudaand, A., and Ulloa, O.: Processes and patterns of oceanic nutrient limitation, Nat. Geosci., 6, 701-710, 2013.
Morgan, C. A., Robertis, A. D., and Zabel, R. W.: Columbia River plume fronts. I. Hydrography, zooplankton distribution, and community composition, Mar. Ecol.-Prog. Ser., 299, 19-31, 2005.

Ou, S., Zhang, H., and Wang, D.: Horizontal characteristics of buoyant plume off the Pear River Estuary during summer, J. Coast. Res., 50, 652-657, 2007.

Raven, J. A.: The twelfth Transley Lecture. Small is beautiful: The picophytoplankton, Funct. Ecol., 12, 503-513, 1998.

St. Laurent, L.: Turbulent dissipation on the margins of the South China Sea, Geophys. Res. Lett., 35, L23615, https://doi.org/10.1029/2008GL035520, 2008.

$\mathrm{Su}$, J.: Overview of the South China Sea circulation and its influence on the coastal physical oceanography outside the Pearl River Estuary, Cont. Shelf Res., 24, 1745-1760, 2004.

Suttle CA, Cochlan, W. P., and Stockner, J. G.: Size-dependent ammonium and phosphate uptake, and N:P supply ratios in an Oligotrophic Lake, Can. J. Fish. Aqua. Sci., 48, 1226-1234, 1991.

Vrede, T., Ballantyne, A. P., Millelindblom, C., Algesten, G., Gudasz, C., Lindahl, S., and Brunberg, A. K.: Effects of N : P loading ratios on phytoplankton community composition, primary production and $\mathrm{N}$ fixation in a eutrophic lake, Freshwater Biol., 54, 331-344, 2009.

Wong, L. A., Chen, J. C., Xue, H., Dong, L., Guan, W., and Su, J.: A model study of the circulation in the Pearl River Estuary and its adjacent coastal waters: 2 Sensitivity experiments, J. Geophys. Res., 108, 249-260, 2003.

Wong, G. T., Tseng, C., Wen, L., and Chung, S.: Nutrient dynamics and $\mathrm{N}$-anomaly at the SEATS station, Deep-Sea Res. Pt. II, 54, 1528-1545, 2007.

Wu, J., Chung, S., Wen, L., Liu, K., Chen, Y. L., Chen, H., and Karl, D. M.: Dissolved inorganic phosphorus, dissolved iron, and Trichodesmium in the oligotrophic South China Sea, Global Biogeochem. Cy., 17, 1008-1016, 2003.

Yin, K., Qian, P., Wu, M., Chen, J., Huang, L., Song, X., and Jian, W.: Shift from P to N limitation of phytoplankton biomass across the Pearl River estuarine plume during summer, Mar. Ecol.-Prog. Ser., 221, 17-28, 2001.

Zhang, J., Yu, Z., Wang, J., Ren, J., Chen, H, Xiong, H., Dong, L., and $\mathrm{Xu}, \mathrm{W}$.: The subtropical Zhujiang (PearlRiver) Estuary: nutrient, trace species and their relationship to photosynthesis, Estuar. Coast. Shelf S., 49, 385-400, 1999. 